\title{
PELATIHAN PERCAKAPAN ANTARA IBU DAN ANAK DALAM BAHASA LOKAL: BERKONTRIBUSI PADA PEMBENTUKAN KARAKTER POSITIF ANAK
}

\author{
Ypsi Soeria Soemantri, Ekaning Krisnawati, dan Eko W. Koeshandoyo \\ UniversitasPadjadjaran Bandung \\ E-mail: ypsi.soeria@unpad.ac.id ; ekaning@unpad.ac.id; ekoeshandoyo@yahoo.com.
}

\begin{abstract}
ABSTRAK. Ketika seorang anak masih balita, ia akan mendapat pendidikan karakter dari orang tuanya. Setelahmasuk sekolah, anak tersebut akan mendapatkan pendidikan formal mengenai pendidikan karakter. Sebetulnya, seorang ibu mempunyai andil yang cukup besardalammembentuk perilakuanak, supayamenjadi anak yang "berkarakter". Anak berkarakter adalah anak yang memiliki karakter positif, yaituanak yang berperilaku baik dan kuat secara mental dan tidak cepat berputus asa, dan anak yang cerdas secara emosional dan kognisi. Percakapan yang baik dan penuh kasih saying dari seorang ibu kepada anakanya memberikan dampak yang sangat positif. Dalam PengabdianKepada Masyarakat diadakan pelatihancara berkomunikasi ibu dengan anaknya dalam membantu membentuk karakter positif anak. Metode yang digunakan dalam penelitian ini adalah metode deskriptif. Teori diambil dari Sibarani (2015) dan Ratna (2014). Hasil yang diperoleh adalah sebaiknya percakapanibu dan anak dilakukan dengan santai, ibu bertanya mengenai kegiatanan, ajukan pertanyaan dengan nada yang ramah, berikan pujian, berbicara mengenaitopik yang menarik bagianak, berdoa bersamasama dan memberikan nasihat tanpa disadari oleh anak.
\end{abstract}

Kata kunci: Percakapan; ibu-anak; pendidikan karakter; positif; bahasa-lokal

ABSTRACT. When a child is in his or her very young age, he or her will learn thepositive character from his or her parents. After he goes to school, he formally gets the character building from his or her teacher at school. In the family, the mother is a person who teaches more of the positive value in building the child'scharacter. The child who gets a good character is the person who iskind and mentally strong without a desperate character, and, emotionally and cognitively good. The objective is to train the mothers, so, they and their child can communicate well. Later it will give the positive impacts to their children's characters. The research uses a descriptive method. The theories are taken from Sibarani (2015) dan Ratna (2014). The results are that the communication between a mother and child should be comfortable for the child, a mothermayask the child's activities, a mother should ask some questions with a friendly tone, a mother gives some compliments, mother can talk about the interesting topics, and a mother, child should pray together, and, a mother may give some advices without being notice by the child.

Keywords: conversation; mother-child; character-building; positive; local language

\section{PENDAHULUAN}

Untuk pertama kali seorang bayi mengenali ibunya melalui suara ibunya, komunikasi atau percakapan antara ibu dan anak terus berlangsung hingga anak tumbuh dewasa. Komunikasi atau percakapan ibu dan anak yang dilakukan secara terus menerus akan memberikan andil yang besar dalam membentuk karakter seorang anak,tentu saja tak terlupakan peran ayah, keluarga dan lingkungan turut andil pula dalam pembentukan karakter seorang anak. Jika keluarga ingin memiliki anak dengan karakte positif, orang-tua, terutama ibunya wajib memberikan contoh-contoh karakter yang positif kepada anaknya. Seorang ibu lebih sering berinteraksi dengan anaknya, biasanya nasihat seorang ibu kepada anaknya akan lebih kena di hatianaknya.Percakapanibu dan anakyang berisi asihat-nasihat yang baik dan penuh kasih saying tentunya akan memberikan masukan yang positif bagi anaknya, dan hal itu akan membentuk karakter yang positif pula. Pendidikan karakter tidak hanya tanggung jawab orang tuasaja, tetapiselain orang tua, pendidikan karakter menjadi tanggung jawab keluarga dan guru dalam satu institusi pendidikan tempat anak tersebut mendapat kanpendidikan.

Seperti kita ketahui, bahwa pendidikan karakter (character building) memiliki andil yang besar pada kemajuan suatu negara. Pendidikan karakter di dalam makalah ini adalah usaha sengaja yang dilakukan untuk membangun karakter seseorang agar menjadi anak yang memiliki karakter yang baik dan kuat secara emosional dan intelektual. Pendidikan karakter ini lebih baik dilakukan terhadap anak sejak anak tersebut dalam usia dini (golden age), karena di awal-awal kehidupan seorang anak, ia akan belajar lebih dalam dan akan mengingatnya terussampaitua. Pelajaran-pelajaran atau nasihat-nasihat dari seorang ibu yang diujarkan dalam 'bahasa ibu', bahasa pertama yang anak tersebut pelajari, yaitu bahasa lokal, diharapkandengan 'bahasa ibu' seorang ibu dan anaknya akan memiliki pendekatan secara emosional yang lebih erat.

Pendidikan karakter berkaitan dengan moral dan watak seorang manusia, oleh karena itu betapa pentingnya'pendidikan karakater' bagi seseorang sejak kecil hingga tumbuh dewasa, untuk mendapatakan bimbingan yang baik, sehingga anak 
itu tumbuh menjadi manusia yang memiliki moral yang baik, dan berbakti kepada orang tua, keluarga, negara, dan manusialainnya. Hal ini sesuai dengan penelitian yang dilakukan Krisnawati,dkk. (2019) bahwa 'bila seorang anak mendapat bekal pendidikan serta pembentukan karakter yang baik dalam keluarga, kemungkinan terjadinya disharmonisasi sosial dalam masyarakat menjadi kecil sehingga terjadinya konflik dapat diminalisir.'

Untuk lebih jelasnya uraian ini mengenai pendidikan katakter, Pendidikan karakter adalah pendidikan untuk karakter, sedangkan"karakter adalah sikap dan cara berpikir, berperilaku dan berinteraksi sebagaiciri khas seorang individu dalam hidup, bertindak dan bekerja sama, baikdalam lingkup keluarga, masyarakat maupun bangsa"(Sibarani, 2014: 138) Karakter dapat memilikimakna yang positif atau negatif, namun dalam pendidikan karakter yang merupakan character building bermakna "membangun karakter yang baik atau positif, berkarakter baik mencakupberperilaku positif dan berjiwa membangun".

Dalam Sibarani, Abourjilie berpendapat bahwa kecerdasan yang berkarakter adalah tujuan akhir sebenarnya dari pendidikan. Pendidikan karakter yang efektif yaitu yang meliputi 'aspek kognitif, afektif, dan psikomotorik, yaitu, pendidikan budi pekerti plus, yang melibatkan aspek pengetahuan (cognitive), perasaan (feeling), dan tindakan (action).'

Di Indonesia, Kementrian Pendidikan Nasional telah merumuskan 18 nilai karakter yang ditanamkan kepada anak-anak Indonesia atau kepada generasi muda Indonesia, dengan rumusan ini diharapkan anak-anak Indonesia akan memiliki moral dan watak seperti: 1) religius, 2) jujur, 3) toleransi, 4) disiplin, 5) kerja keras, 6) kreatif, 7) mandiri, 8) demokratis, 9) rasa ingin tahu, 10) semangat kebangsaan, 11) cinta tanah air, 12) menghargai prestasi, 13) bersahabat, 14) komunikatif 15) gemar membaca, 16) peduli lingkungan, 17) peduli sosial, 18) tanggung jawab (2014:146).

Ke -18 rumusan ini mengandung nilai-nilai watak positif manusia, 'religius'tidak disangsikan lagi bahwa penduduk Indonesia adalah orang-orang yang taat beragama, karena sesesuai dengan sila pertama Pancasila. 'Jujur' dan toleransi adalah sikap positif yang harus dimiliki setiap manusia, jujur tidak suka berbohong dan toleransi kepada orang lain yang mungkin berbeda secara fisik, agama, suku, status dan lainnya. 'Disiplin 'adalah hal yang sangat mendasar untuk menjadi manusia yang sukses dalam kehidupan, seperti disiplin di jalan, di rumah, di sekolah maupun dalam pergaulan di masyarakat. 'Kerja keras dan kreatif'adalah hal yang mendasar lainnya untuk seseorang agar berhasil dalam hidupnya, kerja keras tidak bermalas-malasan dan harus menjadi manusia yang kreatif supaya selalu berinovasi baru, yang dapat menyalurkan rasa ingin tahu.

Selanjutnya,'mandiri dan berprestasi' adalah nilai-nilai yang berhubungan dengan kehidupan seseorang, mandiri tidak bergantung pada orang lain, berprestasi akan menambah nilai kemandirian hidup seseorang. Makna 'demokratis' adalah manusia yang bebas dan dapat menyalurkan inspirasinya. Nilai karakter selanjutnya adalah nilai karakter'bersahabat dan komunikatif', nilai-nilai ini berkaitan dengan hubungan sosial antar sesama manusia.'Semangat kebangsaan, dan cinta tanah air'adalah kewajiban setiapwarganegara. 'Gemarmembaca dan menghargai prestasi'juga berhungan satu dan lainnya. Membaca tentang hal-hal baru sebagai pengetahuan dan dapat menghargai prestasi orang lain. 'Tanggung jawab 'merupakan nilai karater yang tidak dapat dipisahkan dari pembentukan karakter positif seseorang, tentu saja karakter positif seseorang harus peduli pada lingkungan dan keadaan sosial di sekitarnya.

Oleh karena itu, untuk membentuk karakter seorang anak sebaiknya dilakukan sejak bayi ketika kepribadian anak tersebut belum terbentuk. Kemudian pendidikan karakter akan bertambah ketika anak bersekolah, yaitu dengan mendapat pendidikan karakter secara formal di sekolah. Pengajaran berperilaku baik oleh orang tua akan menjadi awal dari pembentukan karakter seorang anak. Percakapan ibu dan anak yang dilakukan dengan 'bahasa' yang baik, dan sopan akan memberikan dampak yang positif kepada anakanak.perkembangan karakter anak, karena "Bahasa sebagai pengembangan kecerdasan intelektual", seperti yang dikatakan oleh Sibarani "Kecerdasan diartikan sebagai kemampuan manusia menjaga keseimbangan antara 'kecerdasan intelektual' dan 'kecerdasan emosional' dalam mengatasi setiap masalah kehidupan sehingga bias membuah kanhasil yang bermutu. " (Sibarani,2004:15). Oleh karena itu, dengan kecerdasan baik secara intelektual maupun emosional, diharapkan ketika seorang anak tumbuh menjadi manusia dewasa, ia akan mampu mengatasi berbagai masalah dalam kehidupannnya kelak.

Pelatihan percakapan ibu dan anak ini dilakukan di desa Sukamantri, Kecamatan Tanjung kerta, Kabupaten Sumedang. Ibu dan anak menggunakan percakapan dalam bahasa lokal, yaitu bahasa Sunda. Kabupaten Sumedang termasuk ke dalam daerah yang disebut dengan 'Parahyanan', yaitu daerah pegunungan yang meliputi dari dari daerah Kabupaten Bogor hingga kabupaten Ciamis. Secara etimologi, 'Parahyangan' bermakna tempat para dewa, 'para rahyang' atau 'hyang' yang mengacu kepada roh leluhur atau para dewa penghun tempattempat yang luhur dan tinggi. 
Sedikit tentang 'Suku Sunda', menurut legenda Sunda, tanah Priangan tercipta ketika para dewa tersenyum dan mencurahkan semua berkah dan restunya. Bahasa Sunda adalah salah satu bahasa lokal (daerah) di Indonesia. Bahasa Sunda berasal dari Bahasa Melayu-Polinesia adalah rumpun Bahasa Austronesia, contoh kata dalam satu rumpun bahasa, lisung (Sunda), lesung (Jawa), lisuh (Kawi), lesong (Madura), lisong (Dayak), losong (Tagalog). Dalam bahasa Sansekerta kata Sunda terbentuk dari akar kata 'sund' bermakna' air, bercahaya, terangbenderang'. Masyarakat Sunda memiliki semboyan yang berkaitan dengan 'etos kerja' masyarakat Sunda, yaitu: cageur (sehat), bageur (baik hati), bener (benar), singer (mawasdiri), dan pinter (pandai/cerdas). 'Cageur' bermakna 'sehat' meliputi sehat secara jasmani maupun rohani. Istilah 'cageur' dalam masyarakat Sunda bermakna masyarakat yang mampu berpikir dan bertindak secara rasional dan proporsional dengan berlandaskan nilai-nilai moral. Lain halnya dengan kata 'bageur'atau baik hati bermakna memiliki sifat kemanusiaan, menjunjung akhlak mulia terhadap sesama. Suku Sunda adalah masyarakat yang paling menjunjung tinggi asas kebersamaan, saling menolong dan gotong royong. Semua berlandaskan atas rasa kasih dan saying antar sesama yang kemudian menciptakan keharmonisan dalam'rumah tangga'Sunda. Terakhir adalah makna 'bener' adalah masyarakat yang senantiasa amanah, tidak berbohong, tidak berkhianat, dan menunjung tinggi integritas yang artinya apa yang diucapan harus sesuai dengan tindakan. Dan etos kerja yang terakhir adalah 'singer' bermakna mawas diri yaitu senantiasa bertoleransi, senang berkorban dan mendahulukan kepentingan orang lain, senang menerima kritikan/masukan dari orang lain terhadap dirinya untuk dijadikan bahan refleksi diri, serta memiliki rasa kasih sayang terhadap sesama.(https:// nasisangu.wordpress.com/2013/07/04/enkulturisasikarakteristik-cageur-bageur-bener-singer-pinter/). Kenyataannya ciri-ciri etos kerja suku Sunda tidak jauh berbeda dengan ke-18 nilai karakter yang wajib ditanamkan kepada anak-anak Indonesia dari Kementrian Pendidikan Nasional dalam pembinaan pendidikan karakter di sekolah-sekolah.

Hal yang menarik lainnya dari Masyarakat Sunda adalah pandangan hidup (filosofi) suku Sunda, yaitu 'Silih Asih', 'Silih Asah', dan 'Silih asuh'. Pertama'Silih asih'memiliki makna saling menyayangi atau mengasihi satu sama lain, pandangan hidup Sunda yang pertama ini berkaitan erat dengan falsafah Negara Indonesia 'Bhineka Tunggal Ika',yaitu walaupun berbeda-beda tetapi tetap satu. 'Silih asih'juga bermakna 'cintakasih sesama manusia, harus saling menghargai satu sama lain, menghormati, tidak boleh bertengkar, tidak boleh membenci karena berbeda etnis atau agama'. Kemudian 'silih asah'memiliki makna saling mengasah, saling menajamkan ilmu, mengasah kecerdasan. Tidak hanya lingkungan sekolah atau universita untuk memberikan ilmu yang seseorang punyai untuk yang membutuhkannnya. Terakhir, 'Silih asuh' bermakna saling membimbing,orang tua dapat membimbing anak-anaknya untuk berperilaku baik, guru-guru dapat membimbing murid-muridnya untuk mendapatkan ilmu, dan para pengajar di universitas dapat membimbing mahasiswanya ke arah berpikir logis dan berperiaku baik dan mendapatkan ilmu yang berguna. Selain kepada putra-putrinya, seseorangyang sudah dapat pendidikan dapat membimbing masyarakt umum untuk menjadi orang baik dan berguna untuk keluarga dan masyarakat pada umumnya.Pandangan hidup orang Sunda juga memiliki kesamaan dengan inti dari rumusan Pendidikan karakter dari Kementrian Pendidikan Nasional.

Bila memahami etos kerja dan pandangan hidup suku Sunda akan memudahkan seorang ibu untuk mendidik anaknya untuk memiliki karakter yang baik. Anak yang berkarakter bermakna anak yang cerdas, anak yang berperilaku baik dan kuat secara mental dan tidak cepat berputus asa. Untuk membentuk anak yang berkarakter, dapat dilakukan dengan pendekatan ibu melalui 'percakapan dengan anak' dilakukan sejak anak tersebut masih berada di dalam kandungan ibunya. Cara bercakap-cakap dengan bayi dalam kandungan di antaranya:

1). Mengajak bicara dengan suara lembut,

2). Mendengarkan lagu bersama,

3). Membaca buku bersama dengan suara lembut,

4). Menceritakan kegiatan sang ibu yang lakukan saat itu, dan sebagainya.

Percakapan ibu dan anak berupa janin masih berupa komunikasi searah, namun hal ini sangat bermanfaat bagi anak karena dapat merangsang pendengaran janin, menstimulasi perkembangan otak, dan, dapat menciptakan suasana yang aman bagi janin.

Selain orang tua, lingkungan tempat tinggal seorang anak turut membentuk karakter anak. Karakter yang baik akan membentuk lingkungan yang baik. Percakapan orang tua dan anak menggunakan bahasa lokal Sunda, oleh karena itu lingkungan yang bersumber dari kearifan lokal turut berperan serta dalam membangun karakter anak. Kearifan local adalah nilai budaya lokal yang dapat dimanfaatkan untuk tatanan kehidupana masyarakat secaraarif dan bijaksana. (2014:115).Orang tua, terutama seorang ibu, harus banyak berinteraksi dengan anaknya. Hal ini untuk menunjukkan kasih sayang orang tua kepada anaknya. Secara tak kasat 
mata, pandangan seorang anak terhadap orang tuanya sebagai idola dalam keseharian hidupnya dan orang tua merupakan panutan bagi anaknya.

Selanjutnya, salah satu dasar pembentukan karakter yang sangat penting untuk diajarkan secara berkelanjutan dan pembimbingan, adalah karakter etika. Karakter etika yang 'baik' yang selayaknya diajarkan oleh orang tua, terutama ibu ,kepada anaknya di lingkungan tempat tinggalnya. Menurut kaidah dari Kementrian Pendidikan Nasional terdapat 15 jenis karakter ini dibagi dalam empat kelompok sesuai dengan hierarkinya dalam pembentukan karakter, kelompok:

1). terpecaya, jujur dan adil, santai dan hormat, kendali diri, bertanggung jawab dan berkomitment.

2). rukun, cinta damai, warga yang baik, toleran

3). peduli dan berbelaskasihan,teguh pendirian dan berintegritas, bersahabat dan komunikatif.

4). demokratis, menghargaiprestasi, berpikir positif dan bersyukur, bersemangat kebangsaan.

(2015:1) Salah satu tema dalam makalah ini adalah percakapan, percakapan berhubungan dengan salah satu dari unsur nomor 3 adalah komunikatif. Komunikatif bermakna pesan dalam percakapan mudah dipahami oleh lawan bicara, dan mudah untuk dihubungi. Bahasa yang komunikatif adalah bahasa yang mudah dimegerti oleh pendengarnya. 'Kemampuan berkomunikasi' adalah kemampuan memililih kata-kata yang tepat, pelafalan kata yang jelas. Menurut Sibarani (2011), sumber komunikatif terdiri atas:

1) menguasai kemampuan bahasa yang dikuasai,

2) menguasa cara berbahasa pada suatu komunitas, contoh bila berbicara ke pada seorang anak tentunya jangan menggunakan bahasa yang sederhana dan mudah dipahami oleh seorang anak,

3) berbicara dengan cara memikat hati,

4) jangan mengunakan bahasa dengan kosa kata yang membingunkan dan lafal yang tidak jelas

5) berusaha berkomunikasi yang berkelanjutan.

Sebagai salah satu upaya menambah pengetahuan bagi para ibu terutama ibu-ibu di desa Sukamantri, Kecamatan Tanjungkerta, Kabupaten Sumedang, program Pengabdian kepada Masyarakat yang kami selenggarakan mengambil tema 'pentingnya komuni kasian taraibu dan anak'karena komunikasi ini merupakan salah satu upaya membangun kedekatan personal. Salah satu cara membangun kedekatan personal adalah melalui komunikasi dalam Bahasa daerah, dalam hal ini adalah dalam bahasa Sunda. Bahasa Sunda yang memiliki nilai-nilai kultural yang agung merupakan salah satu media untuk mewariskan nilai-nilia kesundaan yang sarat makna. Program ini direncanakan dilaksanakan untuk para kader Pembinaan Kesejahteraan Keluarga di setiap dusun yang ada di desa Sukamantri Kecamatan Tanjungkerta mengingat di desa ini masih terdapat keluarga yang kurang memahami bahwa komunikasi antara ibu dan anak merupakan salah satu cara membangun dan mengembangkan karakter anak. Metode Rapid Apraisal dan Participatory Appraisal digunakan untuk mewawancarai dan berdiskusi dengan para ibu penggerak PKK, setelah para kader PKK tersebut mendapatkan materi mengenai penting bercakap-cakap atau berkomonukasi dengan anak-anaknya agar memiliki anak-anak yang memiliki karakter positif. Salah satu contoh, dalam menghadapi fenomena global, kekuatan karakter lokal harus tetap terjaga sehingga tidak tergerus oleh perkembangan asing yang menyusup ke dalam budaya lokal. Pihak Perguruan Tinggi dalam hal ini Universitas Padjadjaran memberikan respon dengan carame lakukan program pengabdian kepada masyarakat mengenai pentingnya.

Komunikasi ibu dan anak melalui cerita sebagai salah satu upaya membangun dan mengembangkan karakter anak. Dalam hal ini, yang akan kami sampaikan kepada masyarakat dalam kegiatan PPM ini adalah edukasi tentang pentingnya berkomunikasi dengan anak dalam 'bahasa ibu' yaitu bahasa local bahasa Sunda yang sarat dengan nilai-nilai luhur kesundaan. Sasaran kami adalah ibu-ibu sebagai kader penggerak PKK di desaTanjungsari, Kabupaten Sumedang, untuk ikut mengembangkan hal tersebut, diharapkan para ibu dapat menjalin komunikasi yang senantiasa menyenangkan dengan anak-anaknya.

Seorang ibu, selain berperan sebagai ibu yang menyayangi anak-anaknya, ibu juga melindungi dan menjaganya; ibu juga harus menjadi seorang sahabat bagi anaknya. Seorang sahabat itu adalah seseorang yang dapat bergembira bersama, bersedih bersama, saling menyayangi, saling menghormati, memaklumi kelebihan dan kekurangan masing-masing dan saling tolong menolong satu sama lainnya. Bila seorang ibu berkomunikasi dengan baik dengan anaknya, seorang anak akan mudah memahami pesan yang disampaikan ibunya, anak tersebut akan mencontoh perilaku ibunya bila ibu berbicara dengan santun, seorang anak berbicara dengan santun pula.

Cara pendekatan ibu dengan anak agar dapat bercaka-cakap dengan baik:

1) menjadi pendengar yang baik

2) sebaiknya tidak membuat asumsi pribadi bila ada hal-hal yang tidak jelas. (lebih baik ditanyakan kembali maksudnya).

3) tidak memotong pembicaraan anak.

4) ketika berbicara, dilakukan kontak mata dengan anak.

5) mengetahui waktu yang tepat untuk berbicara dengan anak 
6) melihat segala sesuatu dari sudut pandang anak

7) tidak perlu berharap anak akan mengatakan sesuatu sesuai dengan ekspetasi ibu (parent. binus.ac.id/2018/06)

Selanjutnya, dari penelitian Krisnawati, dkk (2019), pertanyaan-pertanyaan seorang ibu untuk mengawali percakapan dengan anaknya:

1. Ibu: Tadi marangkat sadaya, A? Mangkat ka sakola? (Tadi semuanya berangkat, A? Berangkat kesekolah?)

2. Ibu: Diajar A wayah bade ulangan teh, awal puasa sugan

(Belajar A kalau sudah dekat waktunya akan ada ulangan, mungkin awal puasa)

3. Ibu: Henteu gaduh PR, A?

(Aa tidak punya PR?)

4. Ibu: Upami Bu Wati ngawulang naon?

(Bu Wati mengajar apa?)

5. Ibu: A, upami sakola sadayana tos nganggo pager? (A, kalau sekolah sudah dipagari semua?)

6. Ibu: Ari ulangan mah pan teu nyandak buku pelajaran, nyandak patlot bae?

(Ulangan tidak membawa buku pelajaran, hanya membawa pensil saja?)

Supaya hubungan seorang ibu dengan seorang anak memiliki hubungan yang lebih erat secara emosional dan fisik, seorang ibu dituntut untuk selalu bercakap-cakap dengan anak-anaknya. Di bawah ini adalah 'beberapa anjuran tema percakapan' dengan anak yang dapat dilakukan secara efektif, sehingga anak akan merasakan manfaatnya.

1. Mulailah dengan pembicaraan anakya, percakapan sebaiknya dimulai dengan kalimat sapaan atau memberikan senyum. Umumnya memulai pembicaraan mengungkapkan kalimat santai dan ringan, seperti dengan kata-kata yang memperlihatkan kasih sayang.

2. Bertanya mengenai kegiatan anak, Percakapan dimulai dengan menanyakan hal apa yang sudah dikerjakan oleh anak. Setelah itu perbincangan bias diteruskan dengan obrolan seputar hal menarik seperti tentang teman dan tempat bermain, dan sebagainya

3. Ajukan pembicaraan dengan nada yang ramah, Seorang ibu penyayang berbicara dengan nada yang ramah dan sopan. Utarakan pertanyaan dengan kalimat yang mudah dicerna. Dengan demikian, seorang ibu bias membuat suasana jauh lebih rileks dan menyenangkan.

4. Berikan pujian jika mendengar hal yang baik, Berikanah pujian apabila anak tersebut melakukan hal baik atau bercerita mengenai kesuksessan. Dengan begitu Ibu akan mengarahkan perbincangan ke arah yang lebih santai dan juga menyenangkan.
5. Carilah topik yang menarik. Selanjutnya pembicaraan dilanjutkan dengan memilih topic pembicaraan yang menarik, misalnya tentang halhal yang menarik bagi anak, seperti sepak bola, film kartun dan lain-lain

6. Berdoa bersama dengan anak. Berdoa bersamasama adalah ajaran etika perlaku yang sangat baik, karena orang tua menjadi panutan anakanaknya. Anak-anak tidak pernah melupakan hal ini sepanjang hidupnya.

Tujuan kegiatan pelatihan ini adalah sebagai upaya untuk menambah'pengetahuan bagi para ibu', terutama ibu-ibu di desa'Sukamantri, Kecamatan Tanjungkerta, Kabupaten Sumedang', untung sering melakukakan percakapan dengan anak-anaknya. Percakapan antara seorang ibu dan putra-putrinya merupakan salah satu upaya untuk membangun kedekatan jiwa. Percakapan ibu dan anak yang menggunakan bahasa Sunda ini mampu memberikan nasehat-nasehat dan wejangan yang menyentuh sanubari anak-anaknya, sehingga anak-anak tersebut akan mendengarkan kata-kata ibunya dan akan menjauhi hal-hal buruk yang akan menjerumuskan dirinya untuk menjadi anak-anak yang berkarakter negatif.

Hasil yang diharapkan adalah pelatihan percakapan ibu dan anak ini dilaksanakan oleh para ibu di desa Sukamantri, Kecamatan Tanjungkerta, Kabupaten Sumedang, sehingga para ibu dapat memiliki emosi yang lebih dekat dengan anakanaknya. Kemudian anak-anak tersebut menerima dan menjalankan semua nasihat-nasihat orangtuanya, terutama ibunya.

\section{METODE}

Metode yang digunakan PPM ini adalah metode Kaji Tindak. Pendekatan ini digunakan untuk menunjukan bahwa kegiatan ini adalah untuk mengembangkan keterampilan-keterampilan ibu-ibu untuk mengajak anak-anaknya bercakapcakap. Pelatihan dan pemberian pengetahuan tentang cara-cara berkomunikasi yang baik kepada anak akan membantu mendidik anak agar anak memiliki 'Karakter Positif'. Kegiatan PKM ini dilakukan dengan pemaparan, pembimbingan dan pelatihan, dan diskusi. Kegiatan ini memberikan contoh-contoh percakapana dan antara ibu dan anak yang menggunakan bahasa lokal. Pendekatan ini dilakukan dengan tahapan sebagai berikut, survey lapangan, rencana kegiatan, pelaksaaan PKM di desa Sukamantri, Kecamatan Tanjungkerta, Kabupaten Sumedang, monitoring, evaluasi, pembuatan laporan pkm dan artikel. Teori- teori pendidikan karakter diambil dari Sibarani $(2004,2015)$ dan Rita (2014). 
Dalam melaksanakan kegiatan PPM ini, digunakan Metode Pemetaan Sosial. Metode yang digunakan adalah metode Rapid Apraisal dan Participatory Appraisal.

Metode Apraisal meliputi :

a. Wawancara informan kunci. Dengan teknik wawancara para dosen memperoleh data dan informasi tentang potensi dan permasalahan yang dihadapi para penggerak Pembinaan dan Keterampilan Keluarga dalam upaya mengembangkan karakter anak.

b. Diskusi kelompok terarah (Focus Group Discussion / FGD). Ini dilakukan terutama untuk kelompok kecil yang beranggotan para kader penggerak PKK di desa Sukamatri, Kecamatan Tanjungkerta, KabupatenSumedang.

\section{HASIL DAN PEMBAHASAN}

Kegiatan dilakukan di Balai Desa Tanjungkerta, Kabupaten Sumedang. Ibu-ibu sebagai kader PKK desa Sukamanti, Kabupaten Tanjungkerta telah hadir. Kemudian para dosen mulai berkenalan dengan ibuibu kader PKK. Para dosen menyiapkan materi dan mulai menjelaskan dengan power point pentingnya komunikasi ibu dan anak dan memberikan contohcontoh percakapan antara ibu dan anak dengan contoh dalam bahasa Sunda. Ibu-ibu mendengarkan dengan penuh perhatian. Dalam penjelasan tersebut,kadangkadang dilakukan permodelan percakapan antara seorang ibu dan anak yang dilakukan oleh para ibu tersebut. Wawancara juga dilakukan kepada ibuibu tersebut untuk mengetahui bagaimana komunikasi para ibu dan putera-puterinya. Setelah itu dilaksanakan sesi diskusi dan tany ajawab. Para ibu sangat antusis dalam berdiskusi untuk memperbaiki cara berkomunikasi ibu dan putera-puterinya. Beberapa contoh perkapan yang diberikan kepada para ibu di antaranaya

a). Mulailah dengan pembicaraan yang santai

Percakapan ini adalah ketika seorang anak baru pulang dari sekolah, ibu menyapa anaknya dengaan penuh kasih sayang. Ibu menggunakan istilah-istilah sapaan yang bermakna 'sayang' dalam bahasa Sunda, yaitu kata 'geulis' (untuk perempuan) atau 'kasep' (untuk laki-laki) . Ibu berbicara dengan katakata yang biasa digunakan untuk anak seperti kata emam dalam bahasa Sunda yang berarti makan. Ibu ini bercakap-cakap secara komuikatif karena anak tersebut dapat menjawab dengan baik dan sopan

Percakapan 1 :

Ujang: Assalamualaaikum Mak

(Assalamualaikum, Bu)

Ujang: Mak, Ujang bade ameung ka lapangan.

(Bu, Ujang mau mainke lapangan)
Emak: Wallaikumsalam, kasep, pan nembe uih sakola, sok emam heula.

(Wallaikumsalam, sayang. Ujang sayang kan baru pulang sekolah, makan dahulua) Ujang: Moal, Mak. Tadi tos emam emih di sakola.

(Tidak, Bu.Tadi sudah makan mie di sekolah) Emak: Teu kenying kitu, ayeuna geura gentos acukna teras emam heula.

(Tidak boleh begitu, sekarang cepat berganti pakaian lalu makan dahulu) Ujang: Sakedap deui, Mak.

(Sebentar, Mak)

\section{b). Bertanya mengenai kegiatan anak}

Seorang ibu bercakap-cakap dengan anaknya dengan penuh kasih-sayang. Percakapan dibawah ini berlansung komunikatif karena anak tersebut dapat menjawab semua pertanyaan ibunya. Percakapan dilakukan dengan sopan dalam bahasa Sunda informal yang biasa dilakukan oleh seorang anak kepada ibunya. Ibu bertanya dengan halus dan sopan, tentunya seorang anak akan menjawabpertanyaan ibu dengan baik dan sopa. Hal ini dilakukan supaya ank tidak membiasakan diri untuk berbohong kepada orang tuanya. Di bawah ini, contoh percakapan dilakukan oleh seorang ibu dengan anaknya yang sudah agak besar yaitu berusia 10 tahun.

Percakapan 2:

Neneng: Emak, Neneng bade ka bumi ibu guru Elis, kenging? Bade ngadamel kueh.

(Ibu, Neneng mau ke rumah bu guru Elis, boleh? Mau membuat kue)

Emak: Geulis, kunaon meuni enggal-enggalan?

(Mengapa cepat-cepat)

Neneng: Bade ka bumi Euis, heula,Mak.

(Mau ke rumah Euis dahulu, ibu)

Emak: Neng bade ngadamel kueh sareng bu guru, Euis bade ngiringan oge?

(Neng mau membuat kue dengan bu guru. Euis juga mau ikut?)

Neneng: Muhun, Mak, bade ngadamel kueh di bumi ibu guru Elis. Euis bade ngiring oge.

(Betul. Bu. Mau membuat kue di rumah bu guru Elis. Euis ikut juga)

c) Ajukan pembicaraan dengan nada yang ramah.

Kehangtan dan keramahan seorang ibu sangat diperlukan dalam percakapan dengan anak. Tanda disadari oleh anaka, seorang ibu menginstruksikan anaknya untuk membersihkan kamarnya. Bila seorang ibu menyuruh dengan nada yang keras, anak akan merasa ketakutan,kemudian membersihkan kamarnya dengan rasa takut, namun bila ibu meminta dengan nada yang ramah seorang anak akan membersihkan kamarnya dengan rasa senang. Hal 
ini akan membentuk karakter positif anak. Contoh percakapan:

Percakapan 3:

Emak: Entin, geulis kamar kedah diberesan sateuacan sakola, supados teu aya sayang reungit.

(Siska, geulis. Kamar harus dibersihkan sebelum pergi ke sekolah. Supaya tidak ada sarang nyamuk)

Entin: Reungit nu aya enjing-enjing tea reungit 'demam berdarah' tea Mak.

(Nyamuk yang muncul pagi-pagi adalah nyamuk demam berdarah, bu?)

Emak: Muhun, reungit nu sok nyeusepan getih dinawaktos enjing-enjing, eta anu midamel Penyakit'demam berdarah' tea,

(betul, nyamuk yangsuka mengisap darah pada hari, yang membuat seseorang kena Penyakit'demam berdarah')

Entin: Naon bentenna sareng ungit anu lianna? (Apa bedanya dengan nyamul yang lainnya)

Emak: Bentenna reungit ieu tiasa midamel awak panas.

(Bedanya myamuk lain tidak membuat menjadi demam)

d). Berikan pujian jika mendengar hal yang baik.

Berikan pujian apabila anak tersebut melakukan

hal baik atau bercerita mengenai kesuksessan. Hal ini akn memberikan anka motivasi untuk terus selalu melakukan hal-hal yang positif yang dapat dibanggakan kedua orang tuanya.Dengan begitu Ibu akan mengarahkan perbincangan kearah yang lebih santai dan juga menyenangkan, seperti contoh percakapan ini:

Percakapan 4:

Emak: Neng geulis, ayeuna mah tos tiasa ngagambar pamandangan, meuni sae pisan.

(Neng cantik, sekarang sudah bisa menggambar pemandangan, bagus sekali)

Nia: Mak, upami tangkalna saena nganggo gambar bubuahan?

(Bu kalau pohon bagusnya ada gambar buahnya)

Emak: Muhun, aya buah jeruk. Warna buah jeruk teh naon neng?

(Betul, ada buah jeruk, warna buah jeruk itu apa?)

Nia: Koneng.

(Kuning)

Emak: Upami kembang eros warnana naon?

(Kalau bunga ros warnanya apa?)

Nia: Beureum

(Merah)

Emak: Aduhhh, putra emak teh meuni pinter pisan, sok teraskeun ngawarnana

(aduh, anak ibu pintar sekali, teruskeun mewarnai gambarnya)
Nia gumujeung.

(Nia tertawa)

e). Carilah topik yang menarik

Selanjutnya pembicaraan dilanjutkan dengan memilih topik pembicaraan yang menarik yang menjadi perhatian anak. Seorang anak akan merasa senang bila percakapan menggunakan topic yang menarik minatnya. Percakapan dengan ytopik yang menarik minat anak, akan memberikan rasa nyaman anak dan membentuk karakter positif anak. Jadi anak akan merasa dekat dengan ibunya dan akan senang dan akan mencurahkan perasaan hatinya kepada ibunya. Percakapan hangat tersebut terdapat dalam contoh percakapan ini

Percakapan 5:

Asep keur diajar ditengah imah, jol indungna naros. (Asep sedang belajar di tengah rumah, muncullah ibunya)

Emak: Kasep, nuju diajar? Sok diajar sing pinter.

(Ganteng, sedang belajar? Belajarlah supaya pintar)

Upami Asep tos ageung hoyong janten naon? (Cita-cita Asep kalau sudah besar ingin jadi apa?)

Asep: Abi mah hoyong sepertos bapak Mak, janten polisi

(Saya ingin seperti ayah $\mathrm{Bu}$, jadi polisi)

Emak: Aduh, Asep pinter pisan hoyong janten polisi, kedah diajar anu rajin supados tiasa janten polisi.

(Wah Asep pintar sekali ingin jad polisi, harus rajin belajar supaya bisa jadi polisi)

Asep: Da janten polisi mah mak hebat, sareng wanteran maot demi nagara

(Menjadi polisi itu hebat dan berani meninggal dunia demi negara)

Emak: Sok atuh emak mah ngadoa wae, mugia citacita Asep kahontal. Asepna kedah rajin diajar tong hilap ngadoa ka gusti Allah nu Maha Suci.

(Betul, ibu hana bisa mendoakan, semoga citacita Asep tercapai. Asep harus rajin belajar jangan lupa berdoa kepada Tuhan yang Maha Esa)

Asep: Siap, Mak. Amin.

(Siap Bu. Amin)

f). Berdoalah bersama dengan anak.

Seorang ibu memberikan teladan dengan memberikan contoh yang baik dan berdoa bersama. Berdoa bersama akan memberikan karakter positif pda anak. Kebiasaan baik ini akan diteladani oleh anak sehingga dia besar nanti. Contoh percakapan mengajak untuk berdoa atau melakukan sholat berama: 
Percakapan 6:

Emak: Geulis, hayu urang sholat magrib sasarengan (Cantik, ayo kita sholat magrib bersamasama)

Eka: Mangga Mak, Eka bade wudhu ti payun, (Iya, Bu. Eka mau wudhu duluan )

Emak: Saatos sholat ngaos doa kanggo nu tos teu araya.

(Setelah sholat membaca doa untuk yang sudah tidak ada)

Eka: Oh, kunaon kedah ngadoa kanggo nu tos teu araya.

(Oh, mengapa harus berdoa untuk yang sudah tidak ada)

Emak: Supados, nu tos teu araya teh dihapunten sagaladosa-dosana sareng ditampikasaeannana. (Supaya yang sudah tidak ada diampuni dosa-dosanya, dan diterima kebaikannya)

g) Memberi nasihat sambal bercakap-cakap

Seorang ibu dapat member nasihat kepada anaknya tanpa disadari oleh anaknya. Agar anak it akan mendengarkan nasihat ibunya dengan baik, nasihat ibu dapat diselipkan dalam percakapan antara ibu dan anak. Dengan cara ini nasihat seorang ibu dapat dipahami anaknya sehingga hal ini akan membentuk karakter positif seorang anak, contoh percakapannya:

Perkapan 7 yang pertama:

Udin: Emak, Udin bade ka lapang bola heula. Bade maen bal sareng Mamat.

(Ibu, Udin ma uke lapanganboladulu. Mau maen bola denganMamat)

Emak: Tos ngadamel PR teu acan, Din?

Udin: Teu acan, Mak. Engke bae ngadamel PR mah. (belum, Bu. Nanti saja membuat PR nya)

Emak: Din, upami tugas mah teu kenging diengkeengke.

(Din, kalua tugas tidak boleh ditunda-tunda)

Sok damel heula PR na, bade direncangan ku Emak waktos ngadamelna.

(Ayo dibuat dahulu PR nya, akan ditemani oleh Ibu ketika membuatnya)

Udin: Hayu atuh. Mak, ngadamel PR ayeuna supados enggal rengse.

(Ayo $\mathrm{Bu}$, buat PR sekarang supaya cepat selesai)

Percakapan 7 yang kedua:

Percakapan ibu dan anak, nasihat ibu yang diselipkan pada percakapan dengan anak. Contoh ke dua: Nining nuju mukaan henpon na.

(Ninings edang membuka telpon genggam)

Emak : Ning, hayu urang ngadamel goreng cau.

(Ning, ayo kita membuat pisang goreng)

Nining: Engke ,Emak nuju ningalian henpon. (nanti $\mathrm{Bu}$, sedang melihat telepon genggam

Emak :Tos lami ningali henponna.

(sudah ama melihat-lihat teleponnnya)

Teu kenging ningalian hanpon lami-lami teuing, bilih socana resak.

(tidak boleh melihat telepon genggam terlalu lama, takut matanya jadi rusak)

Hayu, bantuan Emak ngadamel pisang goreng.

Nining: Tapi engke Nining kenging ningalian gugel deui.

(tapi nanti Nining boleh melihat google lagi)

Emak: Muhun engke, tapi saatos ngadamel PR, ibak sareng emam.Kenying mun sakeudap.

(baiklah nanti tetapi setelah membuat PR, mandi dan makan malam.

Hanya boleh sebentar saja melihatnya).

\section{SIMPULAN}

Percakapan antara ibu dan anak adalah upaya pendekatan secara emosional dan fisik antara ibu dan anak. Selain itu percakapan antara ibu dan anak mengandung unsur-unsur pembentukan karakter positif anak. Dalam pembentukan karakter positif anak, orang tua tidak saja harus menjadi panutan segala perilaku yang baik, tetapi juga percakapan yang berlangsung secara komunikatif tanpa disadari mengajarkan perilaku yang baik kepada anak-anak dari cara bertutur, pemilihan kata yang baik, perilaku bertutur yang sopan akan memberikan pengalaman berkomunikasi yang baik dengan seorang anak. Anak-anak harus belajar dari sejak dini cara mereka bertutur dengan baik, mengemukakan pendapat, berdialog dengan kata-kata yang sopan untuk memiliki karakter positif. Setelah besar kelak anakanak tersebut diharapkan akan memiliki perilaku baik diantatanya 18 karakter etika yang baik.

Kegiatan PKMini belumberhasil sepenuhnya, karena belum semua ibu-ibu di desa Sukamatri, Kecamatan Tanjungkerta, Kabupaten Sumedang, ini hadir untuk mendengarkan, diwawancarai dan berdiskusi. Dalam penelitian ini terdapat beberapa anjuran tema percakapan inti antara ibu dan anak, dengan contohcontohnya yang dapat membantu membentuk karakter positif anak. Diperlukan waktu beberapa kali untuk Kembali ke desa untuk memonitoring apakah ibu-ibu sudah memperbaiki komunikasi kepada putera puterinya supaya mendapatkan puteraputri yang memiliki karakter positif.

\section{DAFTAR PUSTAKA}

Krisnawati,dkk. 2017. Tindak Sosial Dalam Interaksi Domestik: TelaanPercakapan Ibu danAnak Berbahasa Sunda. Lembaga Penelitian Universitas Padjadjaran: Bandung 
Rahyono, F. 2015. Kearifan Budaya dalam Kata. Wedatama Widya Sastra: Jakarta

Ratna, NyomanKutha. 2014.Karya Sastra, Seni dan Budayadalam Pendidikan Karakter.Pustaka Pelajar: Jogyakarta.

Sibarani, Robert. 2014. Kearifan Lokal, Hakikat, Peran, dan Metode tradisi Lisan.Asosiasi Tradisi Lisan : Jakarta

Sibarani, Robert. 2015. Pembentukan Karakter. Langkah-langkah Berbasis Kearifan Lokal. Asosiasi Tradisi Lisan: Jakarta https://nasisangu.wordpress.com/2013/07/04/ enkulturisasi-karakteristik-cageur-bageurbener-singer-pinter/

http://belajarpsikologi.com/pengertian-pendidikankarakter/

http://rumahinspirasi.com/18-nilai-dalampendidikan-karakter-bangsa/

http://cerdasberkarakter.kemdikbud.go.id/

http:Http: //parent.binus.ac.id/2018/06.Komunikasi Effektif Orang-tua dan Anak. 